$\xi=-1$

\title{
Supply Chain Performance Influencer in Construction Domain: A Key Factor Analysis
}

\author{
Vivek Kumar1*, Y.V. RAO2, Vikash Kumar3 \\ ${ }^{I}$ B.E., MS (Engineering), AMIE, C.Eng. MISTE, Ph.D. (Pursuing) \\ ${ }^{2}$ MBA, M.Phil. DCRS, Ph.D., Dean - Research and Development - Garden City University \\ ${ }^{3}$ B.E., M.S., M.B.A. MIE, Research Scholar (Garden City University)
}

\begin{abstract}
In this study the improvement of supply chain process based on the supply chain management has been considered. In this regard, two vital factor of time and cost has been taken into account to optimize the process of product delivery. To harness the available methods, among the all options, the construction company's integration has been elicited in order to improve the business process by concentrating best logistic and supply chain factors to improve the construction quality and standards. By ensuing the proposed methods, the importance of supply chain relationships in construction companies as well as efficiency of the flowed information in terms of relevant data to improve customer and supplier relation has been manifested. In the strategies, followed aforementioned trends, the best potential tools for improvement of constructed companies have been identified. At the end, implementing the mentioned strategies, the obtained results attested the quality performance and supply chain management expediency.
\end{abstract}

Keywords: Supply Chain Performance; Supply Chain Managements; supply chain relationships in construction companies

\section{Introduction}

This examination target to indentify Components influencing Store network execution of the Development Organizations in India to advance arrangements that can support the creation of development organizations by enhancing the execution of supply chains. Organizing the compelling components in the chain in admiration of the significance of each can be surveyed in the development ventures. By institutionalizing and enhancing inside procedures and time-effectiveness will increment and the nature of development will move forward. The investigation adopts a commonsense strategy in classifying the compelling elements in production network the executives of development organizations in India.

By investigation and appraisal of elements impacting the production network of development organizations in the development business is one of the real essentials for creating enhancement in development venture the executives. Then again the development organizations have acknowledged in the current aggressive condition that they can't figure out how to deal with everything all alone.

Store network the board of development organizations is an efficient examination covers the coordination and synchronization of the stream of assets in the development system of providers related, generation offices. The segments of this development organization's system assume distinctive jobs in the production network The procedure begins from crude materials to providers and transforms the materials into conclusive items in the development organizations and disperses the finished result through dissemination focuses. The Inventory network the board objective to run the previously mentioned procedure such that clients are empowered to get solid administrations or items at the most minimal expense and rapidly in development organizations best undertaking administration.

The primary objective of store network the board needed to enhance inventory network process in order to convey the item legitimately to clients with auspicious and at least expense in the development organizations. The perception uncovers that production network the board can enhance responsiveness to clients; increment benefits had drawn the consideration of numerous directors to the idea of inventory network the executives in development organizations.

The key components driving development organizations toward production network the executives demonstrates the requirement for development exercises, expanded re-appropriating plan, expanded transportation cost; and expanded focused pressure, expanded globalization.

The store network is that system of autonomous development organizations that are included through upstream and downstream linkages important in the distinctive procedures and exercises that produce an incentive as items and administrations in development organizations.

The philosophy to distinguish factors in Inventory network The board development organizations pertinent to Benchmarking is dependably a troublesome undertaking to accomplish for reasons, for example, quality, time factor and focused on procedures. There requirement for development organizations arranging/inquire about apparatuses to help administrators choice by taking vision plan, mission pertinent, CSF and key interior business forms development organizations.

Development Organization's mix among those instruments and methods is important to enhance the business procedure by concentrating best coordinations and inventory network elements to enhance the development quality and benchmarks. 


\section{Objectives of the study}

1. Determine CSF and key performance factors relevant to construction project management

2. To study the construction companies related key factors contribution to improve the quality of products and competitiveness

3. To design the best project management system to improve the construction companies profitability and customer satisfaction

4. To offer best plans or models to improve construction companies quality policies and project management practices.

\section{Methodology}

The intentions of pilot research study discover the involvement of supply chain management effectiveness of construction companies. This pilot research study was focused by applying primary research tool called pre-tested questionnaire of five-point likert scale to identify the construction company's success factors. The sample data collected from 150 respondents of 4 construction companies in Bengaluru in the State of Karnataka.

\section{Hypothesis}

H1: The Supply Chain Management Performance of construction companies positively affects Business Performance by considering key factors of project management

H2: The Supply Chain Management Performance of construction companies will not absolutely marks Business Recital by considering key aspects of project management

Nominal supply chain management (SCM) has grown into an important means of fortifying competitive lead and varying organizational enactment since competition is less amongst organizations, but supplementary between supply chains. This research hypothesizes and advances three dimensions of SCM exercise (supplier relationship management, manufacturing flow management, and product development and commercialization) and tests the associations between these SCM practices, competitive advantage, and organizational concert.

Table 1: Key factors affecting on Supply Chain Management

\begin{tabular}{|c|c|}
\hline Factors & $\begin{array}{c}\text { Percentage of influence } \\
\text { on decisions }\end{array}$ \\
\hline Technology based CRM & 62 \\
\hline Technology services to Suppliers & \\
\hline Software to serve its Suppliers & 55 \\
\hline MIS to functional areas & 75 \\
\hline IT Applications & 65 \\
\hline Product Quality & 82 \\
\hline Process Technology & 85 \\
\hline Regulatory Compliance & 56 \\
\hline Production Scheduling & 64 \\
\hline Distribution System & 49 \\
\hline
\end{tabular}

The information for the examination was gathered from unmistakable Development associations and the connections proposed in the structure were tried utilizing measurable systems. The outcomes show that improved dimensions of SCM practice can prompt expanded upper hand and higher authoritative execution. These outcomes have an incentive to both to the scholarly and business universes as they give confirmation of the broadly held conviction of the benefits of compelling inventory network the executives.

Table 2: E-commerce and Supply Chain factors in Construction projects: Factor analysis

\begin{tabular}{|c|c|c|c|}
\hline $\begin{array}{l}\text { System sup- } \\
\text { port }\end{array}$ & $\begin{array}{l}\text { Service sup- } \\
\text { port }\end{array}$ & Information support & $\begin{array}{c}\text { Service } \\
\text { agility }\end{array}$ \\
\hline 1. Product trial & 1. Administra- & 1. Availability of & 1. Availability \\
\hline
\end{tabular}

\begin{tabular}{|c|c|c|c|}
\hline $\begin{array}{l}\text { 2. Product } \\
\text { returns } \\
\text { 3. Accurate } \\
\text { information on } \\
\text { website } \\
\text { 4. Complaint } \\
\text { redressal } \\
\text { 5. After sales } \\
\text { service }\end{array}$ & $\begin{array}{l}\text { tive support on } \\
\text { system } \\
\text { 2. Stability of } \\
\text { system } \\
\text { 3. Ease of } \\
\text { transaction } \\
\text { process }\end{array}$ & $\begin{array}{l}\text { hyperlink } \\
\text { on website } \\
\text { 2. Custom } \\
\text { search function } \\
\text { 3. Product varie } \\
\text { ty 4. Simpli- } \\
\text { fication of user } \\
\text { interface }\end{array}$ & $\begin{array}{c}\text { of } \\
\text { automated } \\
\text { transaction } \\
\text { 2. Relevant } \\
\text { information on } \\
\text { website } \\
\text { 3. Simplicity for } \\
\text { ease of Under- } \\
\text { standing } \\
\text { 4. Delivery time }\end{array}$ \\
\hline
\end{tabular}

The objective is to offer the best supply chain encompasses harmonization and information sharing up and down the method among all stakeholders. With skill facilitating evidence flow, a synchronized supply chain can be intended to encounter the tactical, development, and effective objectives of the construction projects.

Table 3: Factors of Supply Chain factors contributing for the success of Construction Companies

\begin{tabular}{|c|c|c|}
\hline Success Factors & $\begin{array}{c}\text { Factor } \\
\text { Weightage }\end{array}$ & Average \\
\hline Technology based Supply Chain & 65 & 35 \\
\hline Planning for Supply Chain & 54 & 46 \\
\hline Supplier Relationship & 66 & 34 \\
\hline Manufacturing Flow & 78 & 22 \\
\hline Customer Services & 86 & 14 \\
\hline Product Development & 82 & 18 \\
\hline Demand Management & 76 & 24 \\
\hline Order Fulfillment & 68 & 32 \\
\hline Audit System & 70 & 30 \\
\hline
\end{tabular}

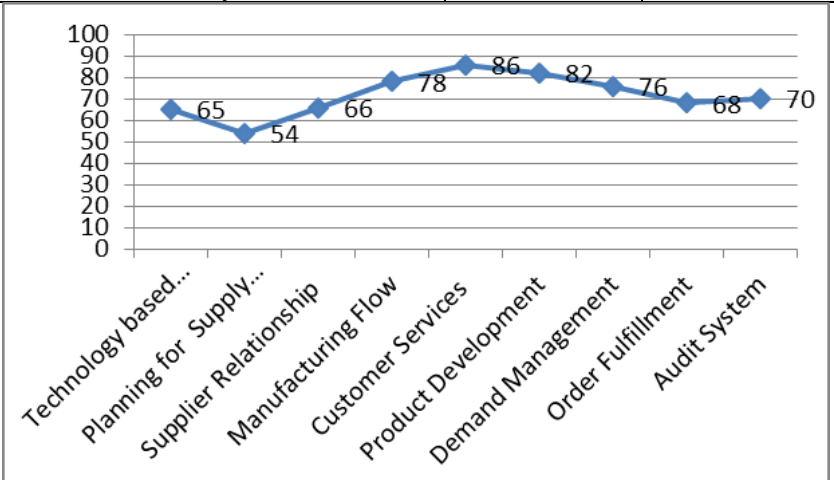

Fig. 1: Factors of Supply Chain factors contributing for the success of Construction Companies

Table 4: Effectiveness of Supply Chain Management

\begin{tabular}{|c|c|c|}
\hline Effectiveness factors & Excellent & Average \\
\hline Right selection of Suppliers & 54 & 46 \\
\hline Purchase System & 76 & 24 \\
\hline Transportation & 82 & 18 \\
\hline Project Management & 76 & 24 \\
\hline Stock Management & 58 & 42 \\
\hline Warehouse Management & 79 & 21 \\
\hline Distribution Management & 80 & 20 \\
\hline Quality of Products & 66 & 34 \\
\hline Best MIS & 72 & 28 \\
\hline Adopting Technology changes & 64 & 26 \\
\hline ERP based Solutions & 72 & 28 \\
\hline Managerial efficiency & 65 & 35 \\
\hline Logistic Systems & 71 & 29 \\
\hline
\end{tabular}




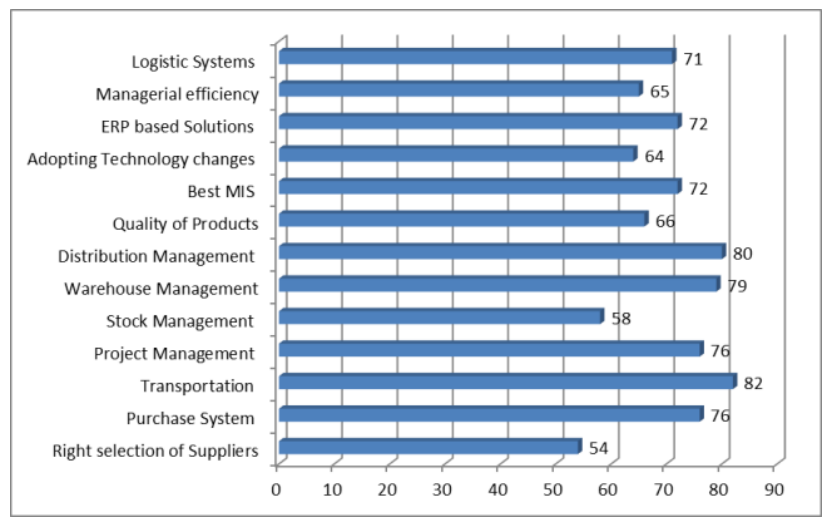

Fig. 2: Effectiveness of Supply Chain Management

\section{Findings and Suggestions}

1. The increasing importance of supply chain relationships in construction companies in respect of project management significance will increase customer satisfaction and achievement of organizational goals.

2. Project administration of development organizations had understand that the stream of data in a best planned way with access to data pertinent to information to enhance client and provider relationship.

3. This Undertaking the executives of development organizations distinguishes data innovation as a best potential instrument for development.

4. Construction organizations ought to likewise know that speed changes in client request viewpoints, globalization of business sectors slants and changing innovation in organizations to focus endeavors on enhancing intensity by method for attempting to accomplish consumer loyalty through increasing the value of their items in Task the executives of development organizations. The implementation of process strategies of construction companies will improve construction projects quality performance and supply chain management performance.

\section{References}

[1] Al-Odeh, M., and Smallwood, J. (2012). Sustainable supply chain management: Literature review, trends, and framework. International Journal of Computational Engineering and Management, 15(1), 85-93.

[2] Aref A. Hervani, Marilyn M. Helms and Joseph Sarkis (2005), "Performance measurement for greensupply chain management", Benchmarking: An international Journal,Vol. 12, No. 4, pp. 330352

[3] Bhattacharya A, Jain R, Choudhary A. Green Manufacturing: Energy, Products and Processes, The Green manufacturing report by The Boston Consultancy Group for Confederation of Indian Industry, India, March 17-18, 2011, New Delhi.

[4] Bio-based chemicals: In need of innovative strategies, Chemical Weekly, February 28, 2012.5.Environmental Performance Index (EPI) Survey report, (2010). 